\title{
DIFUSIÓN Y CRONOLOGÍA DE LA POESÍA BURLESCA DE QUEVEDO: UNA REVISIÓN
}

\author{
RODRIGO CACHO CASAL \\ University of British Columbia
}

En los últimos años de su vida, Quevedo había planeado recoger y publicar varias obras, entre las que se contaba también la edición conjunta de sus poemas. Pero su muerte en 1645 no le permitió llevar a cabo este proyecto. El escritor había distribuido sus versos en nueve grupos, correspondientes a las nueve musas, ordenados por un criterio temático y genérico (poesías amorosas, encomiásticas, morales, burlescas...). El manuscrito que contenía esta colección de versos pasó a ser propiedad del heredero de Quevedo, su sobrino Pedro Aldrete, y el humanista José Antonio González de Salas fue el encargado de cuidar su edición. En 1648 salieron en Madrid las primeras seis musas bajo el título de El Parnaso español, monte en dos cumbres dividido, con las nueve musas castellanas, donde se contienen poesías de don Francisco de Quevedo. En 1670 Aldrete publicó Las tres musas últimas castellanas, terminando la labor de González de Salas, que había muerto en 1651.

Estos dos libros son los testimonios impresos más importantes de la poesía quevediana y, pese a algunos apócrifos que se deslizaron en las Tres musas, recogen unos textos fidedignos y probablemente revisados por el autor. Sin embargo, su aparición tardía y su escasez de anotaciones y comentarios no permiten establecer una cronología aproximada de los poemas ${ }^{1}$. Esta carencia destaca aún más si se comparan el Parnaso y las Tres

\footnotetext{
${ }^{1}$ Para determinar la cronología de la poesía quevediana se han seguido criterios variados y complementarios, como referencias internas o evolución estilística. La labor de J. M. BLECUA en sus ediciones de los poemas de Quevedo ha sido continuada, entre otros, por J. O. Crosby, En torno a la poesía de Quevedo, Madrid, Castalia, 1967, pp. 95-174; R. MOORE, Towards a Chronology of Quevedo's Poetry, Fredericton, York Press, 1977; R. SENABRE, «Hipótesis sobre la cronología de algunos poemas quevedescos», en Homenaje a José Manuel Blecua, Madrid, Gredos, 1983, pp. 605-16; M. RoIG MIRANDA, Les sonnets de Quevedo. Variations, constance, évolution, Nancy, Presses Universitaires de Nancy, 1989; C. VAÍllo, «Hacia una cronología de la poesía satirico-
} 
musas con el Manuscrito Chacón, donde se recogen y se fechan las obras en verso de Góngora. A este problema se le añade otro relacionado con la difusión de las poesías de Quevedo, quien en vida había publicado sólo un número muy reducido de composiciones en algunas antologías como las Flores de poetas ilustres (1605) o las Maravillas del Parnaso (1637). Pese a ello, los contemporáneos pudieron conocer los versos quevedianos a través de manuscritos, pliegos sueltos o en las reuniones de academias literarias. Por ejemplo, la jácara de Escarramán («Ya está guardado en la trena» $)^{2}$ debió circular con mucho éxito desde principios de siglo, como demuestran las menciones que hacen de ella, entre otros, Cervantes, Góngora, Salas Barbadillo o Lope de Vega ${ }^{3}$.

Precisamente el estudio de algunos pliegos con poemas festivos de Quevedo le ha hecho concluir a Edward Wilson que la difusión de sus obras tuvo que ser notable, como indica en el título optimista de un artículo: «Quevedo para las masas» ${ }^{4}$. En el polo opuesto se sitúa Antonio Carreira, quien defiende que fueron pocas las poesías de Quevedo que pudieron conocer sus contemporáneos y que, por tanto, su influjo en otros poetas españoles fue muy reducido hasta mediados del siglo XVII. La escasez de textos impresos y de manuscritos conservados parece indicar que Quevedo debía guardar celosamente sus versos ${ }^{5}$. Pablo Jauralde ofrece una postura intermedia, destacando que si bien es verdad que géneros como la lírica amorosa de Quevedo conocieron escasa difusión hasta la publicación del Parnaso, no ocurrió lo mismo con otras modalidades como la festiva que

burlesca de Quevedo», en La edición de textos. Actas del I Congreso Internacional de Hispanistas del Siglo de Oro, eds. P. Jauralde, D. Noguera y A. Rey, London, Tamesis, 1990, pp. 477-82. Blecua ofrece un índice de poemas fechados en su edición de Quevedo, Obra poética, Madrid, Castalia, 1969-81, 4 vols (III, pp. 549-60).

2 Para los poemas quevedianos sigo el texto y la numeración de la edición de J. M. BlECUA, Obra poética. La jácara de Escarramán lleva el número 849. Modernizo, donde proceda, la ortografía de los textos citados en este trabajo y corrijo sus erratas evidentes.

${ }^{3} \mathrm{P}$. Jauralde Pou indica que ya hay menciones e imitaciones del poema en manuscritos fechables entre 1603 y 1605 (Francisco de Quevedo (1580-1645), Madrid, Castalia, 1998 , p. 265). Cervantes lo introduce como personaje en su Entremés del rufián viudo y reproduce los versos 55-56 de la jácara en el Quijote (II, 26), Góngora lo menciona en su romance «Al pie de un álamo negro» (v. 24) y Salas Barbadillo titula una de sus comedias El gallardo Escarramán. Lope cita a Escarramán en una carta de 1617 y los versos 55-56 de la jácara quevediana en otra de 1615 (Epistolario, ed. A. G. de Amezúa, Madrid, Aldus, 1941, III, pp. 215 y 337). Además, Lope adaptó la jácara de Escarramán a lo divino en el romance «Ya está metido en prisiones», publicado por primera vez en 1613 en un pliego suelto. Ver M. CHEVALIER, «Le gentilhomme et le galant. À propos de Quevedo et de Lope», Bulletin Hispanique, 88, 1986, pp. 5-46 (p. 43, nota 147).

${ }^{4}$ E. M. WILSON, «Quevedo for the Masses», Atlante, 3, 1955, pp. 151-66.

5 A. CARREIRA, «Quevedo en la redoma: análisis de un fenómeno criptopoético», en Quevedo a nueva luz: escritura y política, coords. L. Schwartz y A. Carreira, Málaga, Universidad de Málaga, 1997, pp. 231-49. 
tuvo un público más amplio ${ }^{6}$. Mi trabajo se propone revisar estos supuestos y aportar nuevos datos sobre la difusión y la cronología de la poesía burlesca quevediana.

La poesía culta fue un género para minorías en el Siglo de Oro y se difundió sobre todo a través de manuscritos ${ }^{7}$. Este soporte es extremadamente frágil $\mathrm{y}$, por tanto, la mayor o menor cantidad de testimonios conservados no es un índice infalible para determinar la difusión de un poeta barroco. Los poemas de Quevedo tampoco llegarían a un número demasiado elevado de lectores, pero dentro de ese grupo restringido se cuentan varios autores contemporáneos en los que ejerció una influencia notable. Su fama va asociada sobre todo a sus versos burlescos y satíricos, que merecieron elogios y ataques directos años antes de que se publicara el Parnaso. Por ejemplo, en la séptima silva del Laurel de Apolo (1630) Lope de Vega llama a Quevedo «Juvenal en verso», comparándolo con uno de los mayores representantes de la sátira latina. Muy diferente es el juicio de los detractores de Quevedo que imprimieron contra él el Tribunal de la justa venganza (1635) bajo el pseudónimo de licenciado Arnaldo FrancoFurt ${ }^{8}$ :

Muy virtuosos señores, criminalmente acuso a don Francisco de Quevedo, poeta bastardo, legítimo entremesista, autor de bufonerías, chanzas, apodos, matracas, romances y jácaras rufianescas.

Existen más indicios que permiten concluir que la difusión de la poesía burlesca de Quevedo en su tiempo tuvo que ser importante. Los autores que cultivan este género en la primera mitad del siglo XVII tienen en él a un referente constante, que imitan y admiran. En los versos festivos

\footnotetext{
6 «La transmisión de la obra de Quevedo», en Academia Literaria Renacentista II. Homenaje a Quevedo, ed. V. García de la Concha, Salamanca, Universidad de SalamancaCaja de Ahorros y Monte de Piedad, 1982, pp. 163-72; «La poesía de Quevedo y su imagen política», Política y literatura, ed. A. Egido, Zaragoza, Caja de Ahorros y Monte de Piedad de Zaragoza, Aragón y Rioja, 1988, pp. 41-63; «La poesía festiva de Quevedo: un mundo en libertad», Sobre poesía y teatro. Cinco estudios de literatura española, ed. C. Cuevas, Málaga, UNED, 1989, pp. 43-71. Para una visión de conjunto remito a su libro Francisco de Quevedo.

${ }^{7}$ A. RODRÍGUEZ-MOÑINO, Construcción crítica y realidad histórica en la poesía española de los siglos XVI y XVII, Madrid, Castalia, 19682; V. INFANTES, «En busca del lector perdido: la recepción de la poesía culta (1543-1600)», Edad de Oro, 12, 1993, pp. 141-48; E. L. RiVERS, «La poesía culta y sus lectores», Edad de Oro, 12, 1993, pp. 267-79; I. ARELlANO, «Las aventuras del texto: del manuscrito al libro en el Siglo de Oro», en Unum et diversum. Estudios en honor de Ángel-Raimundo Fernández González, Pamplona, Eunsa, 1997, pp. 43-66.

${ }^{8}$ El tribunal de la justa venganza, en QuEVEDo, Obras completas. Obras en verso, ed. L. Astrana Marín, Madrid, Aguilar, 1932, pp. 1099-163 (la cita en la p. 1103). Aún no se ha podido esclarecer quién fue el autor de esta obra. Se suele atribuir a Pacheco de Narváez y al padre Niseno. Véase P. JAURALDE POU, Francisco de Quevedo, pp. 703-10.
} 
de Alonso de Castillo Solórzano, Jacinto Alonso Maluenda o Salvador Jacinto Polo de Medina se encuentran numerosas imitaciones y préstamos directos de las obras quevedianas ${ }^{9}$. De hecho, Polo de Medina alardea de estas deudas en su Hospital de incurables (1636) ${ }^{10}$ :

\begin{abstract}
Apenas me puse a escribir este discurso en sueño cuando dijo V. m., contra él, el sueño y la soltura, y con tan grandes voces que no me dejaba pegar los ojos, diciendo muy engreído: «No vale, que es imitación de don Francisco de Quevedo». Parécele a V. m. que me he de morir por esto. Pues señor mío de mi corazón, no me pasa por el pensamiento, antes quiero advierta que lo mesmo que V. m. me riñe por injuria, lo tengo yo por aplauso; porque no puedo yo buscarme otra gloria como la de parecerme a un varón tan singular, en todas letras grande.
\end{abstract}

Aquí el escritor murciano está aludiendo a la relación evidente entre su obra y los Sueños. Sin embargo, la influencia de Quevedo se detecta con claridad también en sus versos festivos publicados en 1630 con el título de El buen humor de las musas. Entre las composiciones encomiásticas que se hallan en los preliminares del libro hay una décima de Inés de Padilla donde se le llama expresamente: «ioh tú, Quevedo murciano! / ¡oh tú, primero Marcial!». Este pasaje tiene un doble interés, pues certifica la huella quevediana en Polo de Medina y, además, confirma la difusión de la poesía burlesca del autor del Buscón. El apodo «Quevedo murciano» no se explicaría si Padilla no hubiera tenido a mano tanto las obras en verso de Polo de Mediana como las de Quevedo para poder establecer una comparación entre ellas.

A continuación, me sirvo de los versos de autores como Maluenda o Polo de Medina donde la huella de Quevedo es más evidente, para documentar así la difusión de sus poesías burlescas varios años antes de ser publicadas en el Parnaso, las Tres musas u otras antologías barrocas. Por otro lado, el año de impresión de los poemarios de sus imitadores aporta una fecha ad quem que permite ofrecer una cronología aproximada de las composiciones quevedianas. Junto con estos datos, tengo en cuenta también citas y menciones de sus poesías en algunas obras de la primera mitad del siglo XVII.

${ }^{9}$ Sobre la influencia de Quevedo en la poesía burlesca de Polo de Medina y de Maluenda véanse F. J. DíEZ DE REVENGA, «Polo de Medina entre Góngora y Quevedo», en Polo de Medina. Tercer centenario, Murcia, Academia de Alfonso X el Sabio, 1976, pp. 69-82; y su libro Polo de Medina, poeta del Barroco, Murcia, Real Academia Alfonso X el Sabio, 2000, pp. 173-80; I. AREllaNo, Jacinto Alonso Maluenda y su poesía jocosa, Pamplona, Eunsa, 1987, pp. 36-40; M. CHEVAliER, Quevedo y su tiempo: la agudeza verbal, Barcelona, Crítica, 1992, pp. 184-88.

${ }^{10}$ S. J. Polo De Medina, Poesía. Hospital de incurables, ed. F. J. Díez de Revenga, Madrid, Cátedra, 1987, p. 247. Para su poesía sigo también esta edición y la de las Obras completas, ed. A. Valbuena Prat, Murcia, Academia de Alfonso X el Sabio, 1948. 
1. «¿Por qué mi musa descompuesta y bronca» (núm. 639). Se trata de los tercetos Riesgos del matrimonio en los ruines casados. Sátira, publicados por primera vez en el Parnaso ${ }^{11}$. Blecua, siguiendo una indicación de Astrana Marín, los cree compuestos en Valladolid entre los años 1601 y 1605. Lope de Vega cita un verso (con variantes) de esta sátira en dos cartas: «las (¡Dios nos libre!) faldas con la boca» (v. 312). La más temprana es de 1616: «debía de ser de aquellos por quien dijo Quevedo: 'Las, Dios nos libre, faldas levantadas' ${ }^{12}$. Ello indica que el poema tuvo difusión manuscrita más de treinta años antes de su publicación en el Parnaso. En sus notas, González de Salas afirma que se trata de una composición juvenil de Quevedo: «De las más antiguas la juzgo en que mostró su genio [...]. Asegúranmelo de esa suerte fragmentos que de ella, como anterior, oí yo muy en mi puericia». Estas palabras parecen apoyar la cronología establecida por Astrana, y quizás se trate de una poesía escrita en los primeros años del siglo XVII.

2. «Ya que a las cristianas nuevas» (núm. 708). Se publicó por primera vez entre los Romances varios (1640). Se imprimió también en el Parnaso con el título de Comisión contra las viejas. Blecua reconoce en los versos iniciales una alusión a la expulsión de los moriscos, decretada en diciembre de 1609. Castillo Solórzano parece haber imitado este poema en las redondillas A una vieja muy afeitada, llena de color y rubias las canas que aparecieron en la primera parte de sus Donaires del Parnaso (1624):

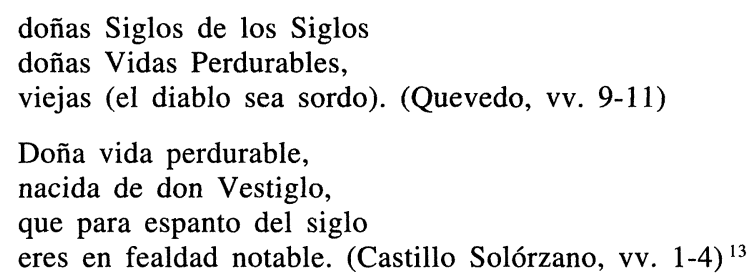

Quevedo empleó a menudo estas construcciones jocosas con el adjetivo perdurable en varias obras festivas en prosa y verso ${ }^{14}$. Sin embargo, el

\footnotetext{
${ }^{11}$ Me ocupo de esta sátira quevediana en mi libro La poesía burlesca de Quevedo y sus modelos italianos, Santiago de Compostela, Universidad de Santiago de Compostela, 2003, pp. 65-93.

12 Epistolario, III, p. 253. La otra cita está en una carta escrita hacia 1617 (III, p. 346). G. G. LaGrone detecta una posible huella de la sátira quevediana en un pasaje de la Corrección de vicios (1615) de Salas Barbadillo. Véase su artículo «Quevedo and Salas Barbadillo», Hispanic Review, 10, 1942, pp. 223-43 (p. 237).

13 A. DE CASTillo SolóRZano, Donaires del Parnaso, Madrid, Diego Flamenco, 1624 , f. 14.

${ }^{14}$ Por ejemplo, el poema núm. 754: «mujer perdurable» (v. 83), o el Sueño de la Muerte: «el mundo está condenado a dueña perdurable que nunca se acaba» (Sueños y discursos, ed. J. O. Crosby, Madrid, Castalia-NBEC, 1993, p. 241).
} 
sintagma completo «doñas vidas perdurables» sólo se halla en el romance Comisión contra las viejas, y Castillo Solórzano debió tomarlo de ahí.

Otro caso cercano es el poema «Viejecita, arredro vayas» (núm. 748), publicado en el Parnaso con este título: Pintura de la mujer de un abogado, abogada ella del demonio. Crosby señala que incluye una parodia de los versos «muchos siglos de hermosura / en pocos años de edad» del romance gongorino «Apeose el caballero» de 1610 , y por tanto debe ser posterior a ese año. Maluenda imitó un pasaje de este poema de Quevedo en sus Redondillas a una vieja que se tiene por niña (en Cosquilla del gusto, 1629). Aparece de nuevo una construcción semejante: «vida perdurable», pero también en este caso la deuda con un poema concreto de Quevedo parece muy probable. Nótese sobre todo la presencia de chistes similares basados en el sustantivo responso:

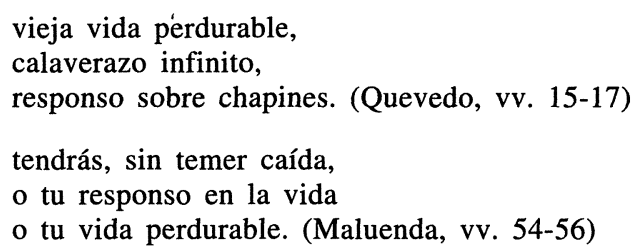

3. «Mensajero soy, señora» (núm. 722). Fue publicado por primera vez en el Parnaso con el título de Lición de una tía a una muchacha, y ella muestra cómo la aprende. Maluenda siguió su esquema argumentativo en el Romance a una taimada vieja y utilizó casi literalmente un pasaje de este poema en su Romance a una tercera del amor y hechicera, ambos impresos en la Cosquilla del gusto (1629):

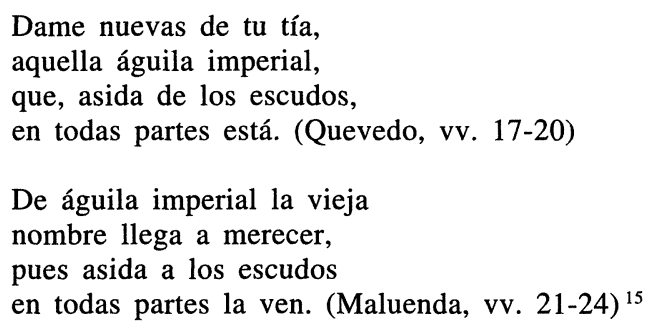

\footnotetext{
${ }^{15}$ Hay un pasaje similar en las Décimas de pie quebrado a una estafante niña de Maluenda, publicadas en el Tropezón de la risa: «pues os contemplo con pico, / y a todo escudo agarradas» (vv. 69-70). Cito las poesías de Maluenda de la antología editada por Arellano en su libro Jacinto Alonso Maluenda y su poesía jocosa. Si el poema en cuestión no se halla en esta selección, lo tomo de la edición de la Cosquilla del gusto, el Bureo de las musas del Turia y el Tropezón de la risa de E. Juliá Martínez, Madrid, CSIC-Instituto Miguel de Cervantes, 1951.
} 
4. «¿Para qué nos persuades eres niña?» (núm. 569). Soneto publicado en el Parnaso con el rótulo Vieja vuelta a la edad de las niñas. Polo de Medina imitó su incipit en la silva $A$ una vieja que dijo tenía dentera de comer limón impresa en el Buen humor de las musas (1630), así como Maluenda en sus ya citadas Redondillas a una vieja que se tiene por niña (en Cosquilla del gusto, 1629):

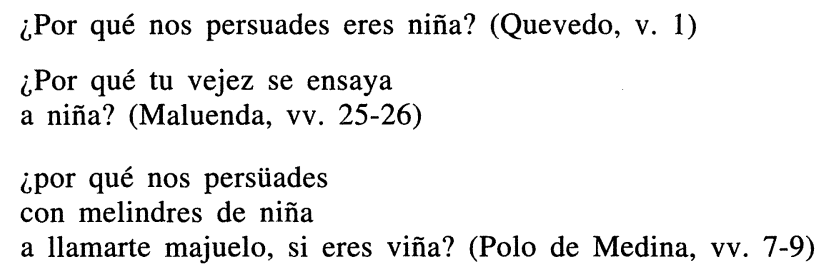

5. «Helas, helas por do vienen» (núm. 866). Publicado por primera vez en los Romances varios (1643), en el Parnaso lleva el marbete de Las valentonas, y destreza. Está estrechamente emparentado con el Entremés de la destreza quevediano. Polo de Medina ofrece una versión paródica a lo divino de los primeros cuatro versos del poema en su Hospital de incurables (1636):

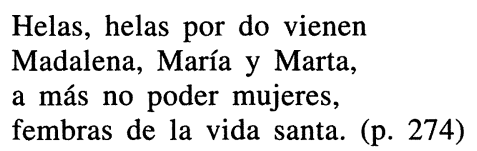

También se menciona este baile de Quevedo y su jácara de Escarramán en el Tribunal de la justa venganza (1635): «siendo lo más de que él puede ufanarse (que otros lo tuvieran por afrenta) el haber hecho el rufianesco romance de Ya está metido en la trena, el friísimo entremés de Cara aquí me voy y la laciva letrilla de Cuchilladas no son buenas» (pp. 1105-06). El texto alude al estribillo del baile: «Cuchilladas no son buenas; / puntas, sí, de las joyeras». Esta composición quevediana debió gozar de bastante fama, pues Maluenda se inspiró claramente en ella para componer un baile impreso en la Cosquilla del gusto (1629):

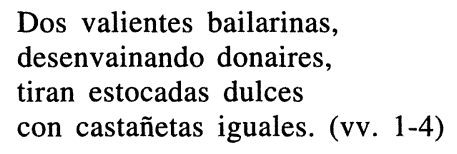

6. «Ansí a solas industriaba» (núm. 721). Fue impreso por primera vez en 1637, en dos antologías que aparecieron el mismo año: Primavera y flor de los mejores romances y Maravillas del Parnaso. En el Parnaso está titulado Documentos de un marido antiguo a otro moderno. Polo de 
Medina pudo haber aprovechado su juego onomástico 'Cornelio Tácito', sobre el cornudo consentido, en un romance («De las espaldas de un monte») del Buen humor de las musas (1630) ${ }^{16}$ :

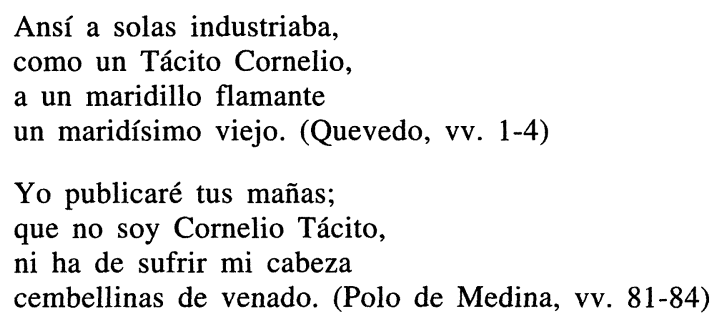

Pero también Maluenda debió apreciar este poema quevediano, ya que imitó su estructura argumentativa (consejos de un cornudo experto a uno nuevo) y varios pasajes en su Romance consolando un sufrido a otro que le han robado la mujer (en Cosquilla del gusto, 1629) ${ }^{17}$ :

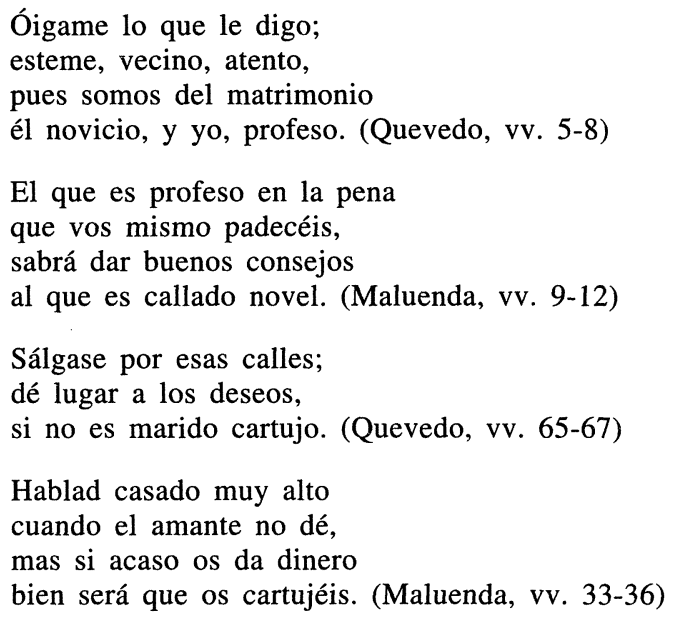

7. «Si la ballena vomitó a Jonás» (núm. 602). Este soneto no se publicó en el siglo XVII. La versión que edita Blecua lleva el título A la ballena y a Jonás, muy mal pintados, que se compraron caros y se ven-

\footnotetext{
${ }^{16}$ Aunque hay que recordar que el chiste Cornelio Tácito-'cornudo consentido' es frecuente en la literatura del Siglo de Oro y podría haberle llegado a Polo de Medina por otra vía. Ver H. N. BERShAS, Puns on Proper Names in Spanish, Detroit, Wayne State University Press, 1961, pp. 44-46.

17 Hay otra poesía de Quevedo que sigue este mismo esquema: la Sátira a un amigo suyo («Que pretenda dos años ser cornudo», núm. 641). Sin embargo, la fuente de Maluenda parece haber sido el romance 721 .
} 
dieron baratos. Maluenda adaptó este poema en su Romance a Silvia (en Cosquilla del gusto, 1629):

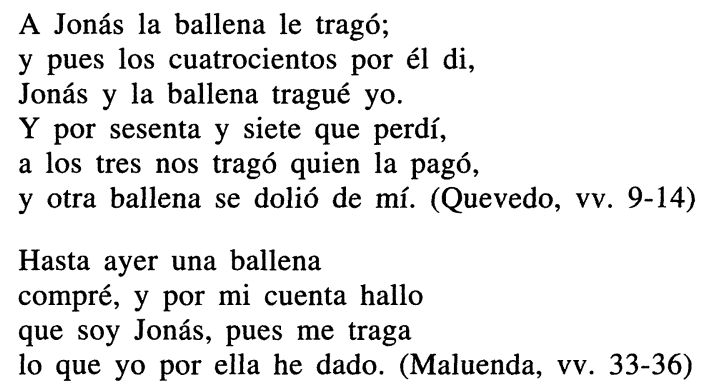

8. «Añasco el de Talavera» (núm. 857). Se imprimió por primera vez en la colección Primavera y flor de los mejores romances (1636). En el Parnaso está rotulado Sentimiento de un jaque por ver cerrada la mancebía. Blecua indica que ha de ser posterior a 1623, cuando Felipe IV prohibió las mancebías. Maluenda tomó prestado un verso de esta jácara para el epitafio $A$ un ladroncillo ratero, incluido en su libro Bureo de las musas del Turia, que se publicó en 1631 pero cuyas aprobaciones son de 1630:

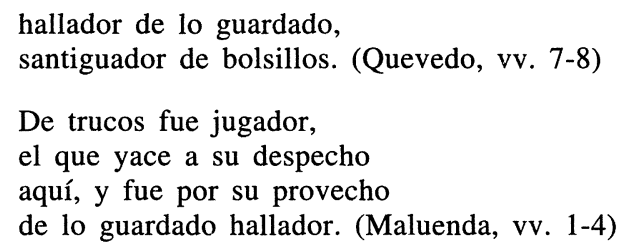

9. «Rostro de blanca nieve, fondo en grajo» (núm. 551). Se publicó en el Parnaso con el título Pinta el 'Aquí fue Troya' de la hermosura. En estos versos Quevedo juega con la rima ridícula (-ajo, -eja, -ujo, -ojo) para describir la vetusta decadencia de una mujer que había sido hermosa en su juventud. Maluenda también se sirvió de este recurso en un soneto donde retrata a una «mujer tomajona y pequeña» (en Bureo de las musas del Turia, 1630) ${ }^{18}$. Varias construcciones y palabras se repiten en ambos poemas, especialmente en posición final de verso (gorgojo, pelleja, abrojo, estropajo). La deuda con la poesía quevediana resulta evidente:

\footnotetext{
18 Acerca de la rima ridícula en la poesía de Quevedo véanse I. AREllano, Poesía satírico burlesca de Quevedo, Pamplona, Eunsa, 1984, pp. 143-45; P. WALDIS, «La rima comica nei sonetti satíricos y burlescos di Quevedo», Studi Ispanici, 1984, pp. 77-101. Arellano también se ocupa de la presencia de este recurso en la obra de Maluenda ( $\mathrm{Ja}$ cinto Alonso Maluenda y su poesía jocosa, p. 22).
} 
Rostro de blanca nieve, fondo en grajo;

la tizne, presumida de ser ceja;

la piel, que está en un tris de ser pelleja;

la plata, que se trueca ya en cascajo;

habla casi fregona de estropajo;

el aliño, imitado a la corneja;

tez que, con pringue y arrebol, semeja

clavel almidonado de gargajo.

En las guedejas, vuelto el oro orujo,

y ya merecedor de cola el ojo,

sin esperar más beso que el del brujo.

Dos colmillos comidos de gorgojo,

una boca con cámaras y pujo,

a la que rosa fue vuelven abrojo. (Quevedo)

Tilde del mismo amor, doña Gorgojo, más podrida, más, vil que el abadejo, pelleja que me dejas sin pellejo, haciendo a mi bolsillo trampantojo, cuya lengua, picando más que abrojo sangra el dinero de un talego viejo:

haz que no cause más tu gran despejo daño a mi bolsa, a su metal enojo.

Si no, de hoy más, serás tú mi espantajo pues de verte pedir, Fabia, me aflijo; no lavará mis platos tu estropajo.

Mi voluntad, errante niña, rijo, que no merece término tan bajo ver el amor que tengo, firme y fijo. (Maluenda)

10. «Que no tenga por molesto» (núm. 668). Se imprimió en las Tres musas de 1670. Maluenda siguió muy de cerca un pasaje de esta letrilla quevediana en la glosa «Los defetos criminal» de su Tropezón de la risa:

Que el escribano en las salas quiera encubrirnos su tiña, siendo ave de rapiña, con las plumas de sus alas; que echen sus cañones balas a la bolsa del potente, ¡mal haya quien lo consiente! (Quevedo, vv. 58-64)

Escribanillo hay que sabe dejar la bolsa lampiña, escribano es de rapiña, nueva con bigotes ave; vuela alegre, agarra grave, y águila caudal en suma, es en garras, es en pluma, pero es ajeno el caudal, ¿quién ha visto tal? (Maluenda, vv. 15-23) 
Sin embargo, este dato no ofrece una fecha segura para determinar una cronología, pues el Tropezón de la risa no lleva año de impresión. Maluenda murió en 1658 y es seguro que compuso esta obra después de la Cosquilla del gusto y del Bureo de las musas del Turia, ya que en los preliminares hay una décima de Pedro Jacinto Morlá donde se alude a estos libros: «de su Cosquilla y Bureo / renacer donoso veo / el Tropezón de la risa» ${ }^{19}$. Hay también otra décima de Alonso de Castillo Solórzano, que residió y publicó varias obras en Valencia, la patria de Maluenda, en los años treinta ${ }^{20}$. La última que vio la luz en esta ciudad fue el Sagrario de Valencia de 1635, y ese mismo año Castillo Solórzano se mudó a Zaragoza siguiendo a su mecenas, don Pedro Fajardo de Zúñiga. Esta fecha, pues, puede servir de término ad quem para la composición del Tropezón de la risa. Añádase a esto que en la dedicatoria Maluenda se refiere al Tropezón llamándolo «sietemesino libro». Podría ser que lo escribiera inmediatamente después del Bureo, y que por tanto sea de $1631^{21}$.

11. «A la Corte vas, Perico» (núm. 726). En el Parnaso tiene el marbete de Instrucción y documentos para el noviciado de la Corte. Guarda notables semejanzas con otro romance de Quevedo, Advertencias de una dueña a un galán pobre («Una picaza de estrado», núm. 713), y sobre todo con su entremés del Niño y Peralvillo de Madrid. Maluenda siguió la estructura de estos versos en los Consejos que le dan a un niño para guardarse de las pedigüeñas de la Corte, romance publicado en el Tropezón de la risa (1631-35). Su imitación es bastante libre, aunque hay algunos pasajes paralelos al texto quevediano, como el incipit que presenta en ambos casos la palabra-clave niño:

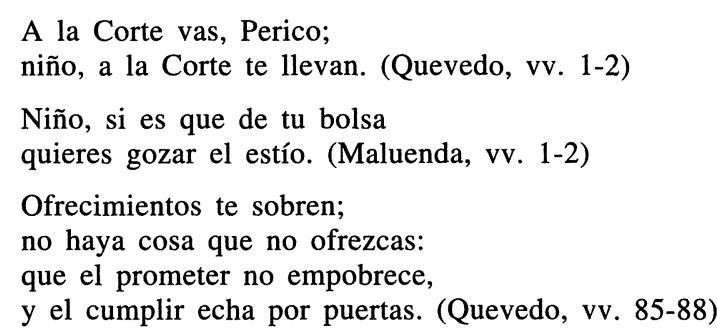

${ }^{19}$ Morlá debió fallecer hacia 1656 , como señala C. A. DE LA BARRERA y LEIRADO, Catálogo bibliográfico y biográfico del teatro antiguo español, desde sus orígenes hasta mediados del siglo XVIII, ed. facsímil, Madrid, Gredos, 1969, p. 281.

20 A. Soons, Alonso de Castillo Solórzano, Boston, Twayne, 1978; P. JAURALDE Pou, «Alonso de Castillo Solórzano, Donaires del Parnaso y la Fábula de Polifemo», Revista de Archivos, Bibliotecas y Museos, 82, 1979, pp. 727-66.

${ }^{21}$ De hecho, según Carreira, el Tropezón fue impreso hacia 1631. Véase su artículo «La poesía de Quevedo: textos interpolados, atribuidos y apócrifos», en Homenaje al profesor Antonio Vilanova, coord. A. Sotelo Vázquez, ed. M. C. Carbonell, Barcelona, PPU, 1989, I, pp. 121-35 (p. 135). 


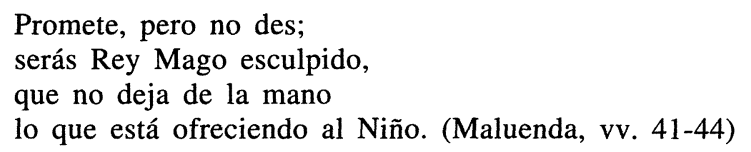

12. «Mi juguete, mi sal, mi niñería» (núm. 628). Esta canción $A$ una mujer pequeña no fue impresa en el siglo XVII. Maluenda parece haberse inspirado en ella para componer su Sátira a las mujeres pequeñas, incluida en el Tropezón de la risa (1631-35) ${ }^{22}$ :

Para un juego de títeres sois dama,

que no para la cama. (Quevedo, vv. 31-32)

Una títere mujer

es un duende con adorno. (Maluenda, vv. 5-6)

que malográis así vuestros deseos,

porque fuerais enana entre pigmeos. (Quevedo, vv. 41-42)

un pigmeo con basquiñas

y un escrúpulo con ojos. (Maluenda, vv. 7-8)

13. «Deletreaba una niña» (núm. 741). Fue publicado en el Parnaso con este rótulo: Refiere la presa de tres salteadoras del sonsaque. Maluenda adaptó unos versos de esta poesía en su Romance a Felisarda, gran pedigüeña (en Tropezón de la risa, 1631-35):

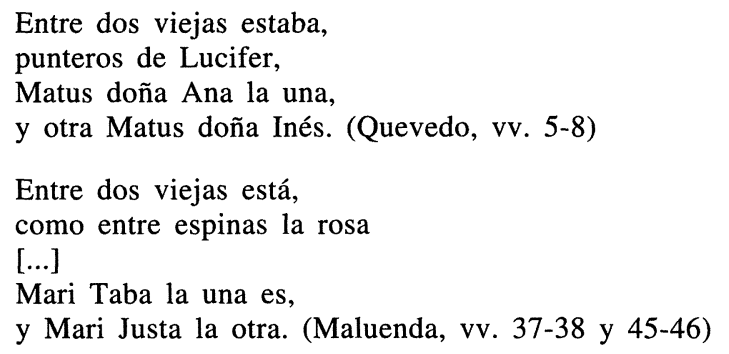

14. «Chitona ha sido mi lengua» (núm. 728). Fue impreso en el Parnaso con el título de Verifica correspondidamente la sentencia vulgar que el medio mundo se ríe del otro medio. Maluenda debió partir de él para componer su Romance que pinta como la mitad del mundo se ríe de

${ }^{22}$ Las semejanzas entre estos dos poemas ya fueron señaladas en las notas de la edición del texto quevediano de F. Plata PARGA, Ocho poemas satíricos de Quevedo. Estudios bibliográfico y textual, edición crítica y anotación filológica, Pamplona, Eunsa, 1997, pp. 226-29. No faltan tampoco paralelismos con la poesía de POLO DE MEDINA, A una dama muy pequeña sobre unos chapines muy grandes, impresa en el Buen humor de las musas (1630). 
la otra mitad (en Tropezón de la risa, 1631-1635). Sin embargo, el poeta valenciano suavizó considerablemente su carga satírica, elidiendo los ataques a la hipocresía social (mujeres artificiales, maridos cornudos, viejos teñidos). De los tipos y clases ridiculizados por Quevedo, sólo permanece la burla a los tuertos:

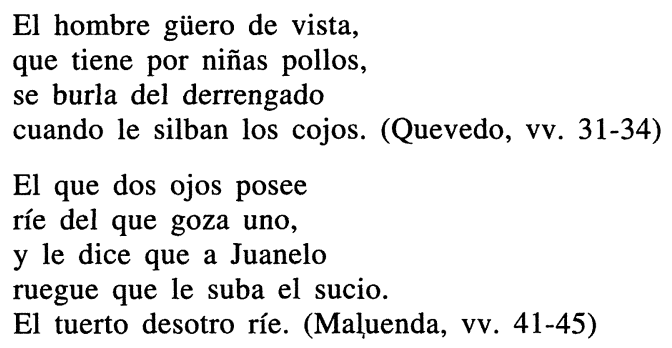

Maluenda podría haber recordado también una agudeza de esta poesía en su Romance a una tercera del amor y hechicera, impreso en la Cosquilla del gusto, lo cual permitiría fechar el poema quevediano antes de 1629. Pero la gracia se repite también en el baile de Las sacadoras («En los bailes de esta casa», núm. 870) de Quevedo y resulta difícil establecer cuál de los dos textos fue la fuente del escritor valenciano:

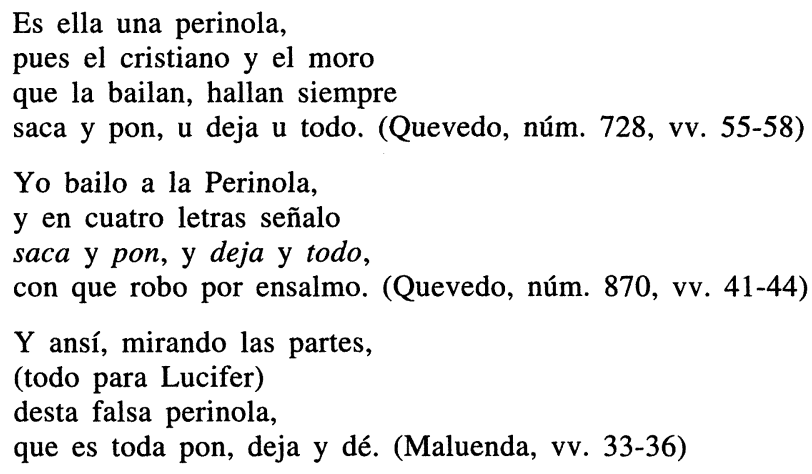

15. «Con enaguas, la tusona» (núm. 815). Este breve poema, que quizás sea fragmentario, se publicó por primera vez entre las Poesías varias de grandes ingenios españoles (1654) con este título: A mi señora doña Ana Chanflón, tundidora de gustos, que de puro añeja se pasa de noche como cuarto falso. Maluenda reinsertó sus versos en la Sátira a las enaguas del Tropezón de la risa (1631-35) ${ }^{23}$ :

\footnotetext{
${ }^{23}$ Por esta razón, Carreira supone que el poema quevediano es apócrifo ( «La poesía de Quevedo», pp. 134-35). Sin embargo, Quevedo es el modelo fundamental de Maluenda y precisamente el hecho de haber sido reutilizado por el escritor valenciano parece reforzar la autenticidad de «Con enaguas, la tusona».
} 


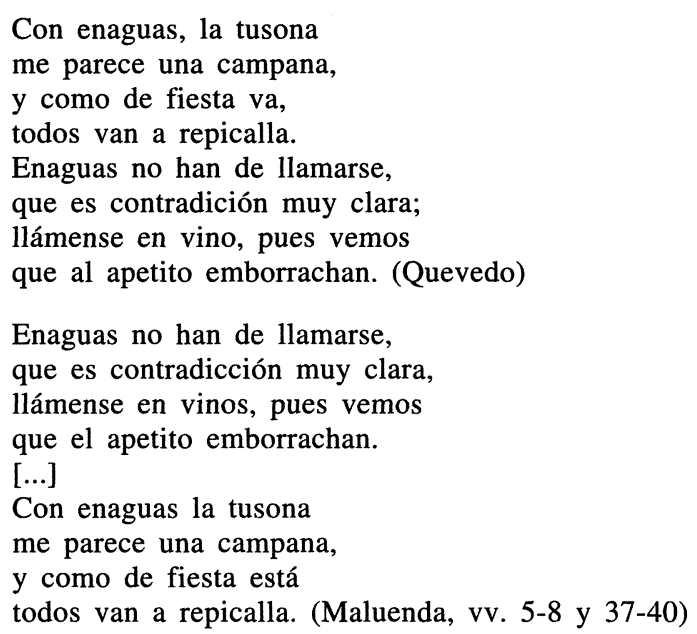

16. «Érase un hombre a una nariz pegado» (núm. 513). Se imprimió en el Parnaso con el marbete $A$ un nariz. Polo de Medina debió manejar alguna de las copias manuscritas que recogían el neologismo archinariz, que en el texto del Parnaso no aparece. De hecho, este soneto quevediano inspiró algunos versos de su romance $A$ unas narices y una boca muy grande del Buen humor de las musas (1630):

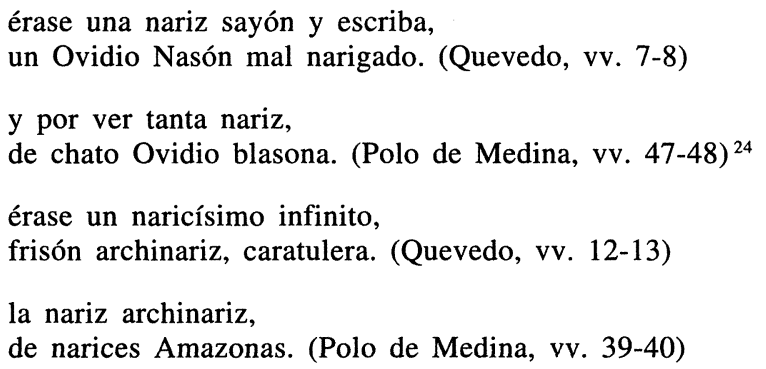

También Lope de Vega parece haber recordado estos versos de Quevedo en su soneto «Si habéis visto al Sofí sin caperuza» de las Rimas de Tomé de Burguillos (1634) ${ }^{25}$. En concreto, el cuarto verso contie-

${ }^{24}$ Polo de Medina repite una burla parecida en la silva $A$ un hombre pequeño de cuerpo, corcovado y con grandes narices (en Buen humor de las musas): «un miquillo con maza de narices, / de quien las de Nasón son aprendices» (vv. 9-10). Como apunta Chevalier, la gracia (Ovidio) Nasón-'narigón' era muy frecuente en el Siglo de Oro (Quevedo y su tiempo, p. 119). Sin embargo, la presencia de este chiste acompañado del neologismo archinariz parece confirmar la deuda con Quevedo.

${ }^{25}$ LOPE DE VEGA, Rimas humanas y divinas del licenciado Tomé de Burguillos y La Gatomaquia, ed. A. Carreño, Salamanca, Almar, 2002, núm. 68. La relación entre este 
ne la expresión «nariz de sayón» que es paralela a la «nariz sayón» quevediana ${ }^{26}$.

17. «Un moño, que aunque traslado» (núm. 742). Se imprimió en el Parnaso con el rótulo Femenina cabellera, que predica a las verdaderas pelambres. Blecua y Crosby detectan una referencia a la pragmática de 1623 que prohibía el uso de cuellos y, por lo tanto, el poema ha de ser posterior a ese año. Polo de Medina lo aprovechó en el romance $A$ una dama que leyendo un papel a la luz de una vela se quemó el moño, de su Buen humor de las musas (1630):

Un moño, que aunque traslado,

de alma y corazón sencillo. (Quevedo, vv. 1-2)

Un moño, sol que en la frenté

de un ángel resplandeció. (Polo de Medina, vv. 1-2)

Que mortal eres te acuerdo,

y que en los pasados siglos,

como tú te ves, me vi;

veráste como me he visto. (Quevedo, vv. 5-8)

¡Oh tú, moño, que me miras,

humilla la presunción;

que cual tú me ves me vi,

y te verás como yo! (Polo de Medina, vv. 25-28) ${ }^{27}$

Fénix soy de las molleras,

renaciendo de mí mismo;

que apenas en unas muero,

cuando en otras resucito. (Quevedo, vv. 33-36)

Fénix de los moños fuera

si en mi ceniza y carbón

poema de Lope y Quevedo ha sido señalada por A. CARREÑo en dos trabajos, «Los engaños de la escritura: las Rimas de Tomé de Burguillos, de Lope de Vega», en Lope de Vega y los orígenes del teatro español. Actas del I Congreso internacional sobre Lope de Vega, dir. M. Criado de Val, Madrid, Edi-6, 1981, pp. 547-63 (p. 559); y «'Que érades vos lo más sutil del mundo': de Burguillos (Lope) y Quevedo», Calíope, 8, 2, 2002, pp. 25-50 (pp. 36-37). La influencia de la poesía burlesca quevediana en Lope ha sido destacada por M. BLANCO, «La agudeza en las Rimas de Tomé de Burguillos», en "Otro Lope no ha de haber». Atti del Convegno internazionale su Lope de Vega, ed. M. G. Profeti, Firenze, Alinea, 2000, I, pp. 219-40 (pp. 224-26).

${ }^{26}$ El sintagma «nariz sayón» aparece en el séptimo verso de la versión manuscrita publicada por Blecua. En el texto impreso del Parnaso se incluye en el tercer verso. Ofrezco otros datos sobre la posible cronología de este soneto en La poesía burlesca de Quevedo y sus modelos italianos, pp. 153-54.

${ }^{27}$ También Maluenda parece haber recordado los versos quevedianos en su Sátira de los moños, publicada en el Tropezón de la risa: «Echó ceniza sobre él, / y en vez de memento homo, / por ver que era de difunto, / le dijo: memento moño» (vv. 45-48). 
volviera a ser lo que fui,

sin ser lo que ahora soy. (Polo de Medina, vv. 65-68)

18. «'Antes que el repelón' eso fue antaño» (núm. 512). Se imprimió en el Parnaso con el título de Encarece los años de una vieja niña. Polo de Medina imitó algunos versos de este soneto quevediano en su romance Escrito en la Academia a un hombre muy viejo que galanteaba una niña (en Buen humor de las musas, 1630):

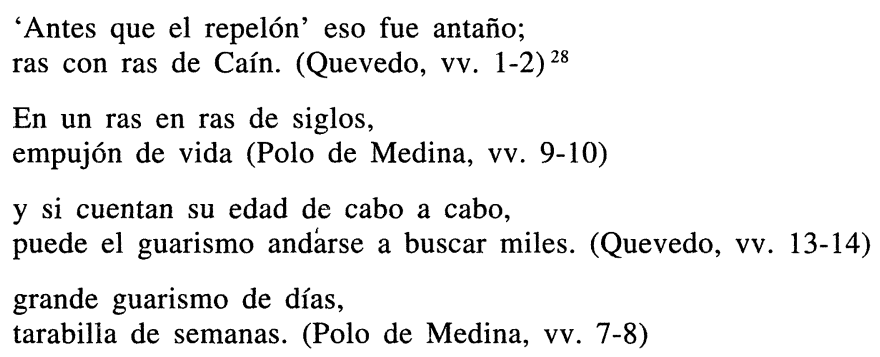

19. «Quéjaste, Sarra, de dolor de muelas» (núm. 526). Se publicó en el Parnaso con el título Mañoso artificio de vieja desdentada. Polo de Medina tomó varios pasajes de este soneto y los adaptó en la silva $A$ una vieja que dijo tenía dentera de comer limón, del Buen humor de las musas (1630):

Quéjaste, Sarra, de dolor de muelas,

porque juzguemos que las tienes. (Quevedo, vv. 1-2) ${ }^{29}$

cuyo son, a pesar de tus cautelas,

nos descubre la falta de las muelas

y que embustera mientes,

pues no hay dentera en boca que no hay dientes. (Polo de Medina, vv. 40-43)

te duelen por ausentes, y, mamando,

bocados sorbes y los sorbos cuelas. (Quevedo, vv. 3-4)

tu niña boca,

con que chupas y mamas. (Polo de Medina, vv. 45-46)

no llames sacamuelas: ve buscando,

si le puedes hallar, un sacaabuelas. (Quevedo, vv. 7-8)

sacamuelas los años que pasaron. (Polo de Medina, v. 32)

${ }^{28}$ La técnica quevediana de utilizar frases hechas para representar la vejez de una mujer se reproduce también en otro romance de POLO DE MEDINA, A una vieja fea y muy melindrosa (en Buen humor de las musas): «Madre de Maricastaña» (v. 1).

${ }^{29}$ Quevedo describe de forma similar a una vieja en el Alguacil endemoniado: «se quejaba del dolor de muelas porque pensasen que las tenía» (Sueños y discursos, p. 153). Sobre el personaje de la vetula en las obras quevedianas y la burla por su falta de dientes véase L. SCHWARTZ LERNER, Quevedo: discurso y representación, Pamplona, Eunsa, 1987, pp. 174-84. 
20. «Una incrédula de años» (núm. 691). Se publicó en el Parnaso con el marbete Acuerda al papel su origen humilde. Blecua detecta una referencia a los cuellos, prenda prohibida por una pragmática en 1623. Polo de Medina recordó una de sus metáforas grotescas contra las viejas («orejón con tocas», v. 55) en su Hospital de incurables (1636): «una dueña (orejón con tocas)» (p. 270) ${ }^{30}$. El poema quevediano pudo servirle también de modelo para su romance $A$ una vieja y fea, que quebró el espejo porque la hacía mala cara (en Buen humor de las musas, 1630), aunque cabe recordar que se trata de un motivo recogido en numerosas obras del Siglo de Oro y que a Polo de Medina le pudo llegar a través de otras fuentes ${ }^{31}$.

21. «En el retrete del mosto» (núm. 745). Publicado en el Parnaso con el rótulo Visita de Alejandro a Diógenes, filósofo cínico. Polo de Medina siguió claramente este poema para componer su romance $A$ Diógenes metido en la tinaja, del Buen humor de las musas (1630). El poeta murciano se centró en la descripción grotesca de Diógenes y prescindió del contenido moral presente en los versos quevedianos:

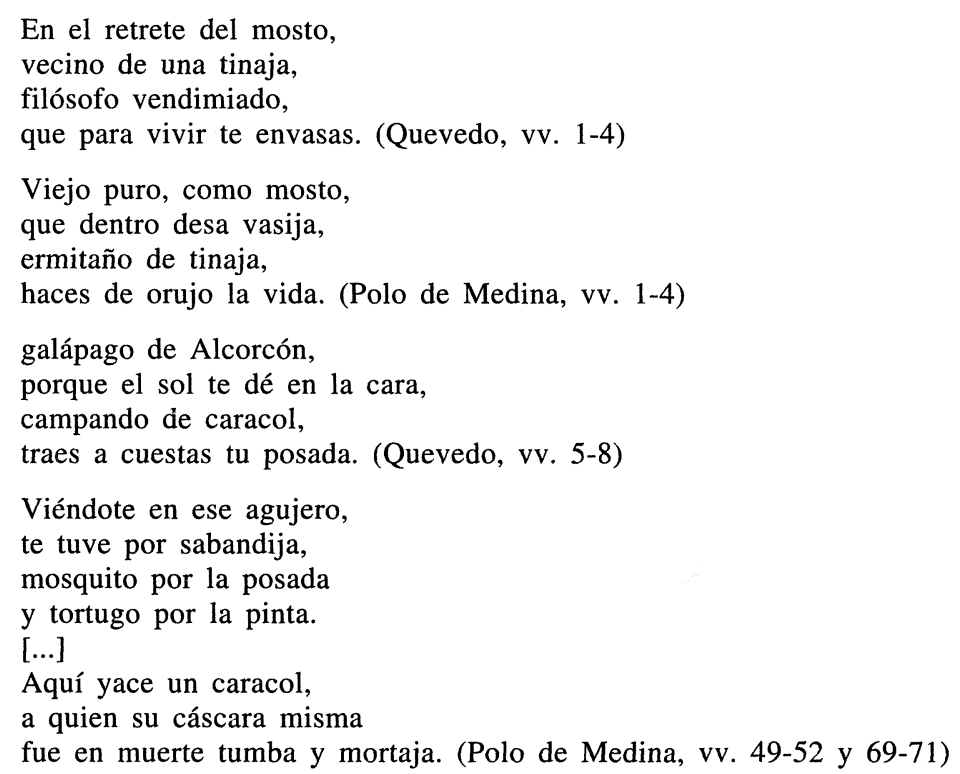

${ }^{30}$ Acerca del uso de la metáfora orejón aplicada a las viejas en las obras quevedianas véase L. SCHWARTZ LERNER, Quevedo: discurso y representación, p. 171.

${ }^{31}$ Documenta su difusión M. CHEVALIER, Cuentecillos tradicionales en la España del Siglo de Oro, Madrid, Gredos, 1975, pp. 187-90. El motivo parece derivar de la Antología griega (VI, 1) y de otros textos latinos, y tuvo muchas imitaciones en los siglos XVI y XVII (J. HUTTON, The Greek Anthology in Italy to the Year 1800, IthacaNew York, Cornell University Press, 1935, pp. 459-60). 
22. «Con mondadientes en ristre» (núm. 689). Impreso en el Parnaso con el título Una figura de guedejas se motila en ocasión de una premática. Blecua y Crosby lo fechan después de 1639, puesto que en ese año se divulgó un pregón prohibiendo llevar guedejas y copetes a los hombres. Sin embargo, la polémica sobre esta moda era anterior, y ya en 1637 Gutierre Marqués de Careaga había publicado en Madrid su Invectiva en discursos apologéticos contra el abuso público de las guedejas. Nótese, además, que el título del poema quevediano menciona una premática y no un pregón. Quizás podría tratarse de la Nueva premática de reformación contra los abusos de los afeites, calzado, guedejas, guardainfantes, lenguaje crítico, moños, trajes y exceso en el uso del tabaco (Zaragoza, 1635) del padre Tomás Ramón. Esta posibilidad se refuerza si se tiene en cuenta que Polo de Medina parafraseó un pasaje del romance en su Hospital de incurables (1636), tres años antes de que se publicara el pregón de 1639:

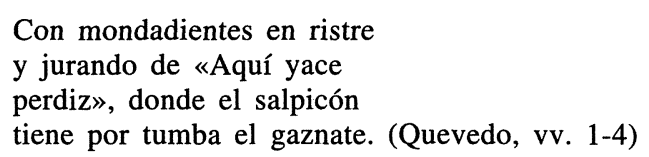

Cuando el otro sale de su casa tascando un palillo en la boca, o batiendo y aleando una plumilla jurándonosla de «aquí yace una perdiz» (cuando él no ha visto aún la de San Nicolás). (Polo de Medina, p. 259)

Pero la cuestión es más complicada, puesto que Polo de Medina citó otro fragmento del poema en sus Academias del jardín, de 1630. Quevedo describe el corte de pelo de su personaje apodándolo «vejiga con ojos» (v. 61), y la misma metáfora es empleada por el escritor murciano: «sirviendo de alcahueta a una calva, vejiga con ojos» ${ }^{32}$. Quizás, la pragmática que inspiró el romance quevediano sea otra anterior a 1630 , que no he sido capaz de identificar.

23. «Zampuzado en un banasto» (núm. 856). Se publicó por primera vez entre los Romances varios (1640). Blecua lo fecha después de 1623, por una alusión al cierre de las mancebías que se decretó ese año. Polo de Medina lo cita en su Hospital de incurables (1636): «¿Delito tan pequeño se os antoja verter el 'Zampuzado en un banasto' a la prisión de San Pedro?» (p. 274).

${ }^{32}$ POLO DE MEDINA, Obras completas, p. 120. Quevedo usa a menudo en su poesía burlesca la voz vejiga para referirse a la calvicie, como documentan S. FERNÁNDEZ MoSQUera y A. AZAUSTRE GaliANA, Índices de la poesía de Quevedo, Barcelona, PPUUniversidad de Santiago de Compostela, 1993. Aparece una metáfora semejante también en el Discurso de todos los diablos: «vejiga empedrada» (en Quevedo esencial, ed. C. C. García Valdés, Madrid, Taurus, 1990, p. 269). 
24. «Ya se salen de Alcalá» y «Hoy la trompeta del Juicio» (núms. 863 y 869). El primero no fue impreso en el siglo XVII y el segundo fue publicado en el Parnaso con este título: Cortes de los bailes. Polo de Medina cita en su Hospital de incurables (1636) dos versos que se repiten en ambos poemas de Quevedo: «El uno es Antón de Utrera / y el otro Rivas se llama» (p. 267). Sin embargo, en «Ya salen de Alcalá» este pasaje se encuentra justo al principio, mientras que en «Hoy la trompeta del Juicio» está en los versos 91-92. Quizás se pueda suponer que el poeta murciano haya tomado el fragmento del primer poema, recordando su incipit, aunque no es posible establecer con seguridad de cuál de los dos textos quevedianos extrajo la cita:

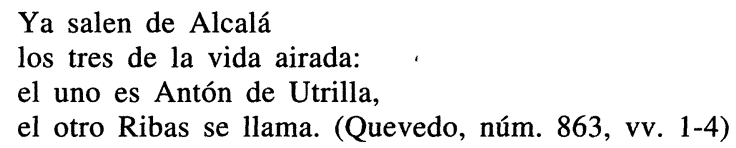

25. «Cruel llaman a Nerón» (núm. 718). Se imprimió por primera vez en los Romances varios (1643). En el Parnaso está rotulado Jocosa defensa de Nerón y del señor rey don Pedro de Castilla. Se alude a este poema en un pasaje de la Trompa, texto satírico atribuido a Juan Pérez de Montalbán, escrito en respuesta a la Perinola quevediana. La Perinola se compuso para atacar el Para todos de Montalbán, publicado en 1632, y Montalbán murió en 1638, con lo cual la Trompa debe fecharse entre 1632 y 1638 :

Dime: ¿quién sino un cojo dijera que Nerón no fue cruel? Digamos algo de esto en alguna conversación, y preguntará alguno: ¿quién dice eso? Responderé: don Francisco de Quevedo en un romance ${ }^{33}$.

Tras este estudio, parece confirmarse que la poesía burlesca de Quevedo tuvo una amplia difusión entre los hombres de letras de la primera mitad del siglo XVII. Varios escritores mencionan sus versos y poetas que cultivan el género jocoso lo siguen como a un modelo fundamental: Lope de Vega, Castillo Solórzano, Maluenda, Polo de Medina y también los anónimos autores del Tribunal de la justa venganza se muestran muy al tanto de sus poemas festivos, años antes de que éstos fueran publicados. Sobre todo Maluenda y Polo de Medina construyen buena parte de sus obras como un diálogo abierto con Quevedo, de quien toman metáforas, chistes y pasajes enteros casi al pie de la letra. A su vez, estas imitaciones directas y

33 J. PÉREZ DE Montalbán, Obra no dramática, ed. J. E. Laplana Gil, Madrid, Turner-Biblioteca Castro, 1999, p. 948. Véase también el estudio y la edición de la Trompa de R. A. Del PIERo, «La respuesta de Pérez de Montalbán a la Perinola de Quevedo», PMLA, 76, 1961, pp. 40-47. 
citas permiten deducir aproximadamente la fecha de composición de algunas poesías burlescas quevedianas.

La huella del ingenio verbal de Quevedo en la literatura del siglo XVII fue honda. Él mismo se encargó de difundir y promocionar sus obras festivas a través de manuscritos y publicaciones. Sus poemas burlescos fueron leídos con detenimiento por un público ávido de agudezas que supo admirar la intensidad y la inteligencia de estos versos desbocados.

\section{APÉNDICE CRONOLÓGICO}

"A la Corte vas, Perico» (núm. 726)

"Ansí a solas industriaba" (núm. 721)

"Antes que el repelón' eso fue antaño» (núm. 512)

"Añasco el de Talavera» (núm. 857)

"Chitona ha sido mi lengua" (núm. 728)

"Con enaguas, la tusona" (núm. 815)

"Con mondadientes en ristre» (núm. 689)

"Cruel llaman a Nerón» (núm. 718)

"Deletreaba una niña" (núm. 741)

"En el retrete del mosto» (núm. 745)

"En los bailes de esta casa» (núm. 870)

"Érase un hombre a una nariz pegado» (núm. 513).

"Helas, helas por do vienen» (núm. 866)

"Hoy la trompeta del Juicio» (núm. 869)

"Mensajero soy, señora» (núm. 722)

"Mi juguete, mi sal, mi niñería" (núm. 628)

"¿Para qué nos persuades eres niña?» (núm. 569)

"¿Por qué mi musa descompuesta y bronca» (núm. 639).

"Que no tenga por molesto" (núm. 668).

"Quéjaste, Sarra, de dolor de muelas" (núm. 526).

"Rostro de blanca nieve, fondo en grajo" (núm. 551)

"Si la ballena vomitó a Jonás» (núm. 602)

"Un moño, que aunque traslado» (núm. 742)

«Una incrédula de años» (núm. 691)

"Viejecita, arredro vayas» (núm. 748)

"Ya que a las cristianas nuevas" (núm. 708)

"Ya se salen de Alcalá» (núm. 863)

«Zampuzado en un banasto» (núm. 856) anterior a $1631-35$

anterior a 1629

anterior a 1630

entre 1623 y 1630

anterior a 1631-35 (¿1629?)

anterior a 1631-35

anterior a 1636 (¿1630?)

anterior a $1632-38$

anterior a 1631-35

anterior a 1630

¿anterior a 1629 ?

anterior a 1630

anterior a 1629

¿anterior a 1636?

anterior a 1629

anterior a 1631-35

anterior a 1629

anterior a 1616

anterior a 1631-35

anterior a 1630

anterior a 1630

anterior a 1629

entre 1623 y 1630

entre 1623 y 1636

entre 1610 y 1629

entre 1609 y 1624

¿anterior a 1636 ?

entre 1623 y 1636 


\title{
RESUMEN
}

Difusión y cronología de la poesía burlesca de Quevedo: una revisión, por Rodrigo Cacho Casal.

La poesía burlesca de Quevedo conoció una importante difusión durante su vida, pese a que hoy se conserven relativamente pocos testimonios impresos y manuscritos. A través de las citas e imitaciones de otros autores de su época es posible deducir el éxito de estos poemas y su fecha aproximada de composición.

Palabras clave: Quevedo, Francisco de, poesía burlesca, imitación, difusión, cronología.

\begin{abstract}
Quevedo's burlesque poetry was very well known during his lifetime, even if today not many manuscripts or printed testimonies exist. Through the quotations and imitations of other authors of his age it is possible to deduce the success and the approximate date of composition of these poems.
\end{abstract}

Keywords: Quevedo, Francisco de, burlesque poetry, imitation, circulation, chronology. 